Bulletin de la Société préhistorique française

Tome 111, numéro 2, avril-juin 2014, p. 211-224

\title{
Uranium-series dating of carbonate formations overlying Paleolithic art: interest and limitations
}

Edwige Pons-Branchu, Raphaëlle Bourrillon, Margaret W. Conkey, Michel Fontugne, Carole Fritz, Diego Gárate, Anita Quiles, Olivia Rivero, Georges Sauvet, Gilles Tosello, Hélène Valladas and Randall White

Edwige Pons-Branchu, Michel Fontugne, Anita Quiles, Hélène Valladas Laboratoire des sciences du climat et de l'environnement (LSCE-IPSL), CEA-CNRS-UVSQ av. de la Terrasse, 91198 Gif-sur-Yvette Cedex

Margaret W. Conkey

Department of Anthropology, University of California, Berkeley, CA 94720-3710 (USA) Raphaëlle Bourrillon, Carole Fritz, Diego Gárate, Olivia Rivero, Georges Sauvet, Gilles Tosello UMR 5608 «TRACES »

Centre de recherche et d'études pour l'art préhistorique, 5 Allées A. Machado, 31058 Toulouse cedex 9

Randall White

Center for the Study of Human Origins, Dept. of Anthropology, New York University, New York, NY 10003 (USA)

\begin{abstract}
The Uranium-Thorium (U/Th) series dating method, developed 50 years ago, has proven its usefulness and reliability for the dating of marine (corals) and continental (speleothems) secondary carbonates deposits. Recently, improvements of the analytical techniques (TIMS - Thermo-Ionization Mass Spectrometry, and then MC-ICPMS - Multicollector-Inductively Coupled Plasma Mass Spectroscopy and laser ablation) allow the dating of very small samples and increase the potential of this method.

Given the difficulties of dating cave art (other than drawings created with charcoal, which can be directly dated by $14 \mathrm{C}$ ), indirect dating methods have been sought. During the last decade, several publications have reported the dating by the U/Th method of thin layers of calcite overlying Paleolithic paintings and engravings or the support of these representations. In these cases, the age of calcite formation is assumed to provide a minimum age (terminus ante quem) for the underlying paintings or engravings or a maximum age (terminus post quem) when it is the support that is dated.

The current article describes the relevance and potential of this method when applied to the dating of calcitic layers deposited above or below prehistoric drawings, together with the specific difficulties encountered in U/Th dating of such thin deposits. An initial difficulty is that thorium may be present in the calcite from the beginning (detritic thorium), making age corrections necessary.

Another difficulty is that in the humid conditions prevalent in caves, the walls may have been subject to runoff over time. In this case, thin calcite layers covering paintings or engravings may have been altered, with possible chemical exchange between the water and the calcite. The most probable effect of this 'open system' behavior is the leaching of uranium, leading to an overestimation of the age of the calcite. Recent applications of the $\mathrm{U} / \mathrm{Th}$ method to the dating of rock art have shown that this phenomenon, if not correctly identified by means of independent methods, may become a significant source of error. For this reason, it is important to know the concentrations of uranium in each calcitic sample, as this makes it possible to detect local anomalies that have led to a substantial loss of this element.

In a recent paper concerning the U/Th dating of eleven Paleolithic decorated caves in the Cantabrian Region (Spain), extremely early dates were determined (more than 41,000 years in one case) and the authors speculated that certain representations could have been produced by Neanderthals. However as detailed analytical data (uranium content) have not been published one cannot appreciate the reliability of the ages obtained. Then, in the absence of confirmation by an independent dating method, it is premature to base an archaeological reasoning on these dates.

This article emphasizes the necessity of carrying out several analyses on the same sample, and when possible on several layers from its thickness. Moreover it is important to perform cross dating using U/Th and 14C (or even using other elements such as $226 \mathrm{Ra}$ or $231 \mathrm{~Pa}$ ) in order to verify the consistency of the results. Several recent examples will illustrate this necessity. It should be also recalled that the calibration curves used to correct radiocarbon ages are largely based on the simultaneous dating by U/Th and $14 \mathrm{C}$ of the same samples of speleothems and corals.

Finally, it has to be mentioned that when the deposits underlying paintings or engravings are studied, the data obtained could be distant in time from the creative act. In fact, the growth of calcite is controlled by environmental factors and is favored during temperate and humid periods. Thus, a large number of calcitic layers overlying paintings could have been deposited during the Holocene. They could also have grown during a brief warming of the last glacial period, or represent a mean age between several growing periods. Nevertheless, these chronological data could bring relevant information, once their validity has been verified.
\end{abstract}

Keywords: U-Th dating, calcite, cave art, Upper Paleolithic, Cantabrian region.

Résumé : La méthode de datation par les déséquilibres dans la série de l'uranium (Uranium-Thorium ou U/Th), développée il y a une cinquantaine d'années, a prouvé son utilité et sa fiabilité pour dater des carbonates secondaires en milieu marin (coraux) ou continental (spéléothèmes). Associée à la datation 14C sur les coraux et spéléothèmes, elle contribue à l'établissement des courbes de calibration de cette méthode pour les derniers 50000 ans (Bard et al., 1990 ; Hoffmann et al., 2010 ; Reimer et al., 2013). L'amélioration des techniques 
analytiques (thermo-ionisation mass spectrometry - TIMS, puis multicollector-inductively coupled plasma mass spectroscopy - MC-ICPMS, et l'ablation laser à laquelle elle peut être couplée) en autorisant la datation U/Th de très petits échantillons, accroît les possibilités de cette méthode. Son application aux voiles de calcite déposés sur des parois ornées (gravures ou peintures) s'est développée au cours des dernières années. Les données chronologiques obtenues représentent, selon l'emplacement du dépôt carbonaté daté par rapport au décor pariétal, un terminus ante quem (situé sur la peinture) ou un terminus post quem (situé sous la peinture). D'abord anecdotiques et limitées à de rares gisements (Bischoff et al., 2003 ; Plagnes et al., 2003 ; Pike et al., 2005 ; Fontugne et al., 2013), ces applications sont devenues plus nombreuses récemment. Ainsi, Pike et al. (2012) ont réalisé une cinquantaine de datations dans onze grottes ornées de la région cantabrique (Espagne), dont les résultats s'échelonnent entre $173 \pm 9$ et $41400 \pm 570$ ans avant le présent. Des âges très anciens ayant été trouvés (supérieurs à 41000 ans dans un cas), les auteurs ont émis l'hypothèse que certaines oeuvres pouvaient avoir été réalisées par l'homme de Neandertal. Bien que fondée sur un seul point de datation, cette hypothèse a été largement reprise par les médias.

Le présent article décrit les difficultés présentées par l'utilisation de la méthode U/Th sur des voiles de calcite. Ces difficultés sont liées, d'une part, à l'évolution géochimique de la calcite en relation avec la circulation hydrique au sein des cavités, qui peut parfois fausser les âges s'il y a eu échanges des radioéléments étudiés entre l'échantillon et son environnement au cours du temps (« système ouvert »), en particulier par lessivage de l'uranium (Plagnes et al., 2003). Elles sont liées d'autre part, à un apport initial possible de ${ }^{230} \mathrm{Th}$ par le biais de matériel détritique qu'il faut prendre en compte pour corriger les résultats.

Ainsi, il est important, lorsqu'il y a des variations notables des teneurs en uranium et des rapports d'activité ${ }^{234} \mathrm{U} /{ }^{238} \mathrm{U}$, dans une même cavité, de tenter d'en expliquer les raisons en relation avec la géomorphologie de la grotte étudiée et de rechercher si les données permettent d'envisager un départ ou une arrivée tardive (système ouvert) de radioéléments. Il est donc fort regrettable que l'article de Pike et al. (2012) sur les grottes espagnoles ne présente pas les teneurs en uranium des échantillons datés et ne discute pas la variabilité des rapports d'activité ${ }^{234} \mathrm{U} /{ }^{338} \mathrm{U}$. L'absence des teneurs en uranium coupe court à toute discussion sur la possible mobilité (départ) de ce radioélément par lessivage qui aurait conduit à un vieillissement des âges U/Th et, de ce fait, il n'est pas possible d'apprécier la pertinence des données chronologiques, même si la mesure sur l'ICPMS, en elle-même, n'est pas à remettre en cause. À titre d'exemple, on peut calculer que si la teneur en uranium de l'échantillon qui a donné l'âge le plus vieux avait été à l'origine $10 \%$ plus élevée (i. e. $10 \%$ de l'uranium parti par lessivage), l'âge réel serait 37000 ans et si elle avait été $15 \%$ plus élevée l'âge réel serait 35000 au lieu des 41000 ans obtenus. Il est donc important, pour valider les âges, de vérifier que les conditions d'application de la méthode U/Th sont réunies, voire de conforter les résultats de l'U/Th avec ceux d'autres méthodes de datation. De fait, le ${ }^{14} \mathrm{C}$ permet aussi de dater les formations carbonatées, même si son application à la calcite prélevée en grotte n'est pas exempte de problèmes, liés en particulier à la présence plus ou moins importante de carbone mort dont la proportion doit être estimée et prise en compte pour corriger l'âge (e.g. Goslar et al., 2000 ; Hua et al., 2012).

Ainsi, la confrontation des résultats obtenus sur les mêmes échantillons par les méthodes U/Th et ${ }^{14} \mathrm{C}$ est une nécessité pour tester leur fiabilité et leur cohérence respective. Plusieurs exemples récents ont illustré l'intérêt de croiser ces deux méthodes sur les voiles de calcite recouvrant des peintures rupestres ou sur des spéléothèmes, pour démontrer la non validité des âges obtenus (systèmes ouverts), ou au contraire les conforter (e. g. Labonne et al., 2002 ; Plagnes et al., 2003 ; Fontugne et al., 2013).

Mentionnons enfin que lorsque les dépôts recouvrant les oeuvres pariétales sont analysés sur toute leur épaisseur, on obtient des âges moyens qui peuvent être fort éloignés du geste créateur que l'on souhaite dater. En effet, la croissance des voiles de calcite est contrôlée principalement par des facteurs environnementaux (températures et précipitations à l'extérieur), cette croissance étant favorisée en période tempérée et humide, et ralentie ou arrêtée en période climatique froide et aride. Bon nombre de dépôts de calcite recouvrant les oeuvres sont tardiglaciaires ou Holocène (les derniers 12000 ans) et donc bien postérieurs à la réalisation des tracés, ou ils datent d'un bref épisode de réchauffement du stage isotopique 3, ce qui nous rapprocherait de l'âge de la création. Les âges déterminés sur les voiles de calcite peuvent aussi représenter un âge moyen entre plusieurs phases de croissance. Quoiqu'il en soit, ces informations apportent des éléments de réflexion utiles, une fois que la validité des âges est vérifiée au plan méthodologique.

Mots-clés : datation U/Th, calcite, art pariétal, Paléolithique supérieur, région cantabrique.

For a century, Paleolithic cave art has been the subject of intense research as a result of its potential to shed light on the mental and spiritual characteristics of prehistoric societies. The major preoccupations of the archaeologists who are concerned with it have been stylistic studies and the chronology of cave art. Until recent years, the chronology of prehistoric works of cave art have been primarily based on the $14 \mathrm{C}$ method, as the accelerator mass spectrometry technique, using less than one mg of carbon per analysis, enables the direct dating of drawings - and paintings - produced with charcoal (Arnold et al., 1987). Our knowledge of the appearance and development of cave art in the early Upper Paleolithic has been greatly enhanced as a consequence (Valladas et al., 2001a and b). Unfortunately, this technique cannot be applied to all cave art works, as only a small number of these were created using charcoal or other organic materials that could be subjected to $14 \mathrm{C}$ dating methods. In the past decade, as a result of their inability to directly date the paintings, researchers have begun taking an interest in the calcareous deposits that can cover some decorated cave walls, and dating these by means of the disequilibrium in the uranium series (U-Th) has been suggested. In fact, this dating method, developed fifty years ago, has proven its usefulness and reliability in dating corals and in determining sea level variations, thus providing information on climatic development during the Quaternary period (Thuber et al., 1965; Edwards et al., 1987). More recently, it has also been applied in continental studies in order to date speleothems for palaeoclimatology studies, and particularly to reveal more humid periods (Van and Lalou, 1969; $\mathrm{Li}$ et al., 1989). It is also coupled to the $14 \mathrm{C}$ dating of corals and speleothems in order to establish the calibration curve (Bard et al., 1990; Hoffmann et al., 2010; Reimer et al., 2013). Following the improvement of analytical techniques (TIMS, ThermoIonization Mass Spectroscopy and then MC-ICPMS, Multi Collector Inductively Coupled Plasma Mass Spectroscopy and laser ablation, to which it can be linked) that make possible the U-Th dating of very small samples, the applications for U-Th dating of thin calcite layers deposited on decorated cave walls have increased significantly in recent years. Initially anecdotal and limited to very rare deposits (Bischoff et al., 2003; Plagnes et al., 2003; Pike et al., 2005; Fontugne et al., 2013) these 
applications have recently become more numerous. Thus, Pike et al. (2012) examined eleven decorated caves in the Cantabrian region of Spain, including Altamira and El Castillo, carrying out around 50 datings with results between $173 \pm 9$ and 41,400 \pm 570 years BP. Depending on the location of the calcareous deposit dated, these data represent a terminus ante quem (located over the painting) or a terminus post quem (located underneath the painting). These results imply a long tradition of decoration of these caves; longer than has previously been thought. Unfortunately, as pointed out by Bednarik (2012) and Clottes (2012) although these results have been widely reported by the media they have as yet received little critical analysis.

Given the magnitude of the implications of these dates, it seemed to us appropriate to reflect on the specific difficulties encountered during the application of U-Th dating to the calcite veils deposited on decorated cave walls.

These difficulties are linked in part to the geochemical development of the calcite within the caves in relation to the water circulation that may sometimes distort dates if there have been exchanges of the studied radioactive elements between the sample and its environment over time (an 'open system') by leaching of the uranium, for example, as demonstrated by Plagnes et al. (2003). Difficulties are also linked to a possible initial ${ }^{230} \mathrm{Th}$ content from detritic material (clay, etc.) that must be taken into account in correcting the results. To these methodological difficulties we must add those associated with sampling the neoformed calcite, which must be free of any contamination by the surrounding limestone, any inclusion of which would distort the date obtained (Fontugne et al., 2013).

It is therefore important when validating the dates obtained to verify that the conditions under which the U-Th method is applied are correct, or even to confirm the results by other dating methods. In fact, the radiocarbon dating $\left({ }^{14} \mathrm{C}\right)$ method also enables calcareous formations to be dated. This method should therefore also be used on calcite from cave art wall samples, particularly as the technique of ${ }^{14} \mathrm{C}$ measurement by accelerator mass spectrometry (AMS) requires only small quantities of material. The comparison of the results obtained for the same samples by these two independent methods would enable an appreciation of their respective consistencies.

In the following account, we will briefly present the principle of the U-Th method, the difficulties in applying it, and the importance of linking U-Th ages with those obtained by ${ }^{14} \mathrm{C}$ dating.

\section{DISCUSSION OF THE LIMITS AND OF CORRECTIONS LINKED TO THE U-Th METHOD}

As they are formed, 'secondary carbonate deposits' such as calcite veils or speleothems incorporate uranium and little or no thorium, as this latter element is relatively poorly soluble in surface and sub-surface waters such as the percolating water that circulates in caves. The thorium $\left({ }^{230} \mathrm{Th}\right)$ is created over time by the decay of uranium $\left({ }^{234} \mathrm{U}\right)$, these two elements achieving 'secular equilibrium' in around 500,000 years, which constitutes the upper limit for application of this dating method.

However, dates are only valid if two conditions are present:

- evolution of the $\mathrm{U}$ and $\mathrm{Th}$ in the mineral within a closed system, i.e. without exchange (addition or loss) of these radioelements with the exterior;

- correction for any initial content of thorium $\left({ }^{230} \mathrm{Th}\right.$ and $\left.{ }^{232} \mathrm{Th}\right)$ of detritic origin, which may have been incorporated during the formation of the mineral.

These difficulties, which may bias the U-Th dates, are discussed below.

\section{The case of an open system}

In general, open systems lead to the mobility of the uranium. Such cases may occur particularly when the calcite is subject to runoff, such as the veils of calcite deposited on cave walls (dissolution/recrystallization, see for example Borsato et al., 2003 or Plagnes et al., 2003) or pulverulent calcite, which is more easily modified.

In order to appreciate the behaviour of the uranium $\left({ }^{238} \mathrm{U}\right.$ and its daughter $\left.{ }^{234} \mathrm{U}\right)$ within dated calcareous deposits, it is important that both levels and activity ratios $\left({ }^{234} \mathrm{U} /{ }^{238} \mathrm{U}\right)$ are published in the case of speleothem dating; this is even more essential in the case of delicate samples such as calcite veils.

Particularly in the case of different samples carried out for a single cave wall or panel, these levels provide information on the possible mobility of this radioelement; a determining factor in the validation of the U-Th date.

Experience shows that on the scale of a single panel, and a fortiori on the scale of the cave, the levels of uranium in calcitic veils are extremely variable, clearly illustrating the complexity of this type of deposit. Such variability is more rarely observed in the case of flowstone or other stalagmitic formations. As for the ${ }^{234} \mathrm{U} /{ }^{238} \mathrm{U}$ ratios, when measured in speleothems they are generally higher than one.

Leaching leads to a preferential loss of ${ }^{234} \mathrm{U}$ compared to ${ }^{238} \mathrm{U}$ through the phenomenon of alpha recoil, and surface or subsurface waters such as karstic flows are thus enriched in terms of ${ }^{234} \mathrm{U}$ (Fleischer and Raabe, 1978; Osmond and Ivanovich, 1992). In other less common cases, the ${ }^{234} U{ }^{238} U$ ratios measured in speleothems may be less than one where the percolating water has dissolved the uranium from areas subject to intense leaching. These variations in uranium isotope levels and ratios may be linked to climatic factors (temporal variation in a single site, for example linked to biological activity in the soil underlying the cavity, see Hellstrom et al., 2000), to lithological variability in the case of covered karsts (Jaillet, 2000; PonsBranchu, 2001) or to travel times or routes for percolating water that vary from one part of the cave to another. When there are significant variations in uranium levels and activity ratios for a single cave, it is important to attempt to explain the reasons for this in relation to the geomorphology of the cave studied or the possibility of late dispersal or arrival (open system) of radioelements.

It is therefore regrettable that the article by Pike et al., (2012) on the Spanish caves does not state the uranium levels in the dated samples and does not discuss the variability of the ${ }^{234} \mathrm{U} /{ }^{238} \mathrm{U}$ ratios. The absence of information on the uranium levels makes impossible any discussion of the possible uranium mobility by leaching that might have led to an upward distortion of U-Th dates. It is also worth noting that, for the cave of El Castillo, ${ }^{234} \mathrm{U} /{ }^{238} \mathrm{U}$ activity ratios show extremely variable values of between 1.1048 and 4.9939 , with only three samples out of eight giving a ${ }^{234} \mathrm{U}^{238} \mathrm{U}$ ratio lower than 1.5 (average $2.837 \pm 1.3$ ). The sample that produced the earliest date $(\mathrm{O}-83)$ is also that which presents the lowest ${ }^{234} \mathrm{U} /{ }^{238} \mathrm{U}$ activity ratio. The ${ }^{234} \mathrm{U} /{ }^{238} \mathrm{U}$ ratios are also extremely variable for the samples from the caves of La Pasiega $\left({ }^{234} \mathrm{U} /{ }^{238} \mathrm{U}\right.$ between 2.1559 and 7.857$)$ and Tito Bustillo $\left({ }^{234} \mathrm{U} /{ }^{238} \mathrm{U}\right.$ between 0.7366 and 1.9757$)$. For the latter, the values presented are either lower than one — which is rarely 
observed - or clearly higher, which indicates the complex geochemical history both of the karst and the water percolating into the cave to produce these calcareous veils.

Complementary investigations in each of the Spanish caves studied (analysis of water, calcite sampled elsewhere in the studied caves, repetition of datings) would have been necessary to provide us with information regarding the geochemical development of the percolating water and/or that of the calcite veils.

These investigations would perhaps have enabled us to understand how the oldest sample from El Castillo (O-83, Panel de las manos) dated to $41,400 \pm 570$ years, presents a uranium signature different from the samples from the same cave (such as layering of the cave with different pathways for the water). We could, for example, evaluate the impact of leaching of part of the uranium originally contained in the sample. In this way we could calculate that if the uranium levels in the original sample were $10 \%$ higher, the real age would be 37,000 years; if it had a content that was $15 \%$ higher, the real age would be 35,000 years instead of the 41,000 years obtained and reported.

\section{Corrections for the initial (or detritic) ${ }^{230} \mathrm{Th}$}

This correction, regularly applied in geochronology, is based on the quantity of ${ }^{232} \mathrm{Th}$ present resulting from the detritic phase, and on a supposed ${ }^{230} \mathrm{Th} / 232 \mathrm{Th}$ ratio for this detritic phase. It is generally accepted that when the ${ }^{230} \mathrm{Th} /{ }^{232} \mathrm{Th}$ ratio is greater than 20 , the detritic phase present has a small effect on the ages determined, even if correction is always desirable. The values of ${ }^{230} \mathrm{Th} / 232 \mathrm{Th}$ ratios generally used for the 'correction of detritic thorium' in the case of datings of speleothems fall between $1 \pm$ $50 \%$ and $1.5 \pm 50 \%$. But other studies have shown that the value of the ${ }^{230} \mathrm{Th} /{ }^{232} \mathrm{Th}$ ratio, when measured or deduced from the stratigraphic constraints, in fact varies from 0.2 to 18 and sometimes even more (Hellstrom, 2006; see summary of various works in Zhao et al., 2009). These corrections lead to only minor modifications in the ages calculated if the level of contamination is low.

Let us return to the article by Pike et al. (2012) and examine the effect of the correction of the detritic portion for the oldest sample (O-83; Panel de las manos) dated to $41,400 \pm 570$ years, assuming that the calcite was not subject to an open geochemical system following its deposition. With a value for the ${ }^{230} \mathrm{Th} / 232 \mathrm{Th}$ ratio of $2.5 \pm 0.5$ instead of $1.25 \pm 0.625$, the corrected age becomes less than 39,000 years, or a reduction of more than 2000 years. Given the importance of the archaeological interpretations that have been drawn from the dates, these two points should be discussed by the authors.

Testing the hypothesis of the closure of the geochemical system and appreciating the relevance of the corrections applied to UTh ages thus remain an essential stage in confirming the reliability of results. This operation is possible when we can carry out multiple datings of a single sample by adhering to the 'stratigraphy' of the deposits. For example, the determination, in the case of a stalagmite or calcitic veil, of several ages 'in chronological order' in relation to the axis of growth is an indication enabling the corrections to be confirmed or even adjusted, given that the different levels of a speleothem generally have different contamination levels. It was possible to carry out this type of verification in the case of a calcite veil with a total thickness of $2.5 \mathrm{~mm}$, sampled from a decorated wall in a cave in East Timor, for which successive layers of $0.1 \mathrm{~mm}$ could be dated by uranium series (Aubert et al., 2007). The results demonstrate remarkable archaeological accuracy. The upper layer on which those paintings were created has an age of 6300 years (terminus post quem), which is in agreement with data resulting from Austronesian archaeology. In addition, a fine layer of red pigment located within the calcite veil, $1 \mathrm{~mm}$ from the surface, could be circumscribed in time by the dating of layers of a thickness of $0.1 \mathrm{~mm}$ located immediately beneath and above the pigment (fig. 1). This was deposited between 29,000 years (terminus post quem) and 24,000 years ago (terminus ante quem). The range is still wide, but the information is much more accurate than if the layer had been analyzed as a whole.

Unfortunately, it is not often possible to carry out this stratigraphic verification in the case of very thin calcite veils that can often only be the subject of a 'single dating'. The precautions to be taken in interpreting the data are thus more important for this type of study. Pike et al. (2012) discuss this aspect, however, and offer measurements of a number of aliquots for several samples in order to appreciate the consistency of the results, but the samples thus studied are not identified (fig. S1 of the additional documentation in Pike et al., 2012).

Finally, we should emphasize the non-negligible risk of removing a variable quantity of the substrate of geological age when sampling these fine veils, as demonstrated by Fontugne et al. (2013) who detected the existence of such contamination and discussed its impact on U-Th datings of calcite from the decorated sites of Piaui (Brazil). The precautions to be taken in interpreting the data are thus more important for this type of study.

\section{APPLICATION OF 14C DATING TO CALCAREOUS DEPOSITS AND RELEVANCE OF U-Th CROSS DATING WITH OTHER METHODS}

Even though ${ }^{14} \mathrm{C}$ dating of calcite is not exempt from problems, particularly in connection with the presence of dead carbon, the comparison of the results of U-Th and ${ }^{14} \mathrm{C}$ methods applied to calcareous deposits from cave art walls is a necessity in testing their respective reliability and consistency. The problem of the incorporation of dead carbon (lacking or poor in ${ }^{14} \mathrm{C}$ ), deriving from the surrounding limestone or from ancient carbon in the soil, has been the subject of numerous studies (see for example Vogel and Kronfeld, 1997; Genty et al., 1999 and 2001; Goslar et al., 2000; Hua et al., 2012). Dissolved in the water at the time of the crystallization of the calcareous deposits, this would lead to an apparent 'ageing' of the ${ }^{14} \mathrm{C}$ dates. Experience shows that the level of dead carbon (without ${ }^{14} \mathrm{C}$ ) generally lies between 5 and $20 \%$, leading to a correction varying between 400 and 1,800 years at the most. This correction, which is independent of the age of the sample, may be estimated from the study of recent/ subactual concretions sampled in the site studied.

This cross dating is also facilitated by the fact that the analytical techniques (accelerator mass spectrometry for ${ }^{14} \mathrm{C}$ and multi collector inductively coupled plasma mass spectrometry for U-Th) requires only very small samples; around 20 milligrams to a few hundred milligrams for ${ }^{14} \mathrm{C}$ and $\mathrm{U}$-Th respectively, which limits the sample size and the resulting destruction of the paintings. 


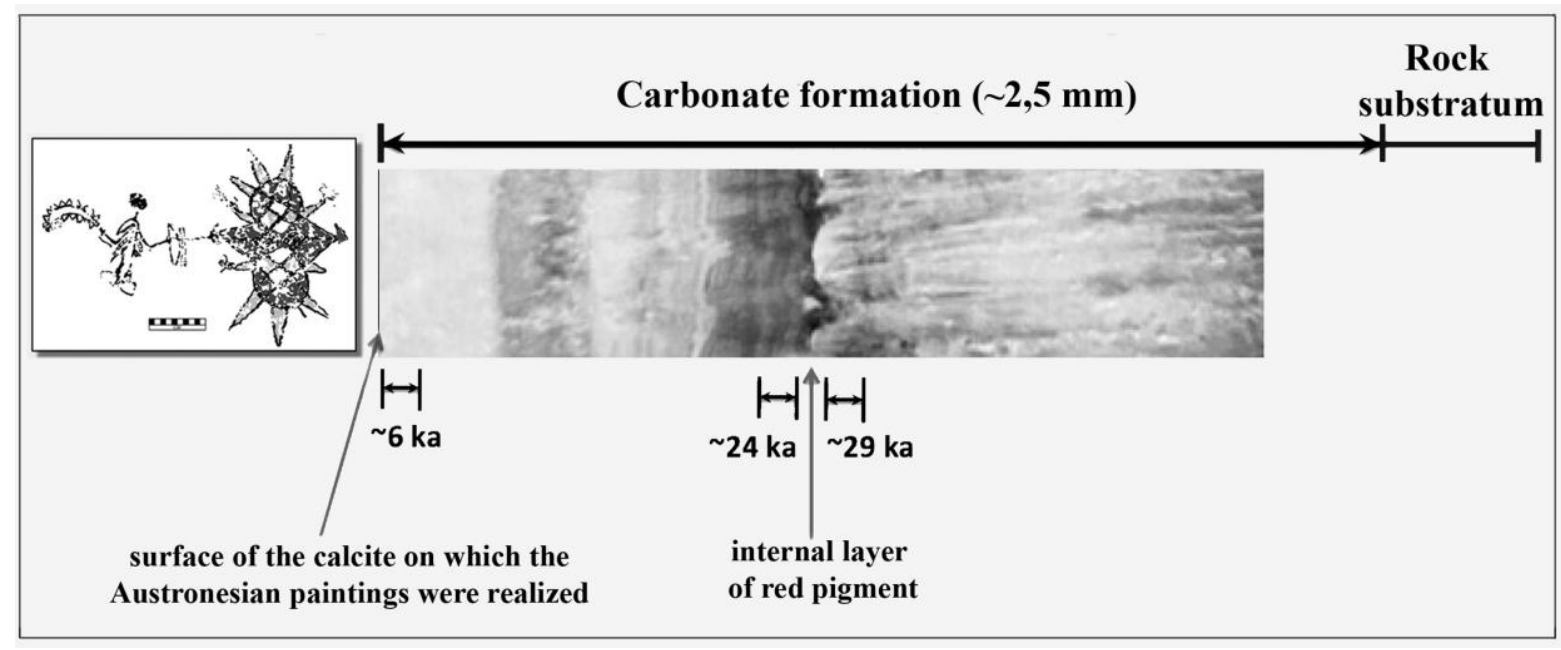

Fig. 1 - Analysis of a calcite layer covering wall paintings in a cave in East Timor, by laser ablation of layers $0.1 \mathrm{~mm}$ in thickness (after Aubert et al., 2007).

Fig. 1 - Analyse d'une couche de calcite recouvrant des peintures pariétales dans une grotte du Timor oriental, par ablation laser de couches de 0,1 mm d'épaisseur (d'après Aubert et al., 2007).Tome 111, numéro 2, avril-juin 2014, p. 211-224. 215

The work of Plagnes et al. (2003) on the comparison of U-Th and ${ }^{14} \mathrm{C}$ ages obtained for the same samples of a calcareous drapery deposited on the surface of a stenciled handprint in the cave of Gua-Saleh (Kalimantan, Borneo) illustrates the relevance of this approach. Three samples removed from different points of this drapery were dated by the two methods. The ages obtained - around 9,900 years - agreed well in only one case out of three, suggesting that the paintings, aged in excess of 10,000 years, were produced before the arrival of the Austronesian population. In another case, the results of the two methods (12,560 \pm 130 for the U-Th method and circa $9000 \mathrm{cal}$. BP for ${ }^{14} \mathrm{C}$ assuming 5\% of dead carbon) differed by a few millennia, which was interpreted in terms of a modification of the geochemical system of one or the other, if not both methods, but the ages nevertheless fall at the end of the Pleistocene. For the third sample, however, the U-Th age was three times greater (circa 27,000 years) than that of the $14 \mathrm{C}$ (circa 9000 years), suggesting that the U-Th dating was affected by a significant systematic error linked to the degradation of the drapery by the runoff waters and to the resulting dispersal of the uranium. A similar approach associating the comparison of U-Th and ${ }^{14} \mathrm{C}$ ages was employed in the decorated shelters of the Serra da Capivara National Park in Piaui (Brazil) on the calcareous deposits formed above the paintings (Fontugne et al., 2013). For some of these samples, the comparison of the results demonstrated the impact of the limestone contaminations of the wall on the U-Th ages, which were found to be considerably older than the ${ }^{14} \mathrm{C}$ results. In still other cases (such as those of the U-Th and ${ }^{14} \mathrm{C}$ cross dating of a speleothem from the Altamira cave in Spain, see Labonne et al., 2002), these cross datings enabled the validation of the chronology inferred from these two methods. These three articles (Plagnes et al., 2003; Fontugne et al., 2013; Labonne et al., 2002) illustrate the importance of comparing the results of two dating methods for the same samples of calcareous deposits in order to appreciate their respective consistencies. It is regrettable that a similar approach was not employed by Pike et al. (2012), particularly in the case of the oldest samples from El Castillo (O-83; Panel de las manos). These examples also demonstrate the importance of carrying out multiple datings when the thickness of the sample allows it in order to test the stratigraphic order of the results.

Finally, we should mention other dating methods, as yet unused in the case of decorated caves, which are based on disequilibria in the uranium family and employ measurements of radium $\left({ }^{226} \mathrm{Ra}\right)$ or protactinium $\left({ }^{231} \mathrm{~Pa}\right.$, Cheng et al., 1998). These have already proved to be of interest in establishing cross-chronologies and validating (or disproving) U-Th dates of calcareous deposits. In this way, the conjuncture of $\mathrm{U}-\mathrm{Th}$ and ${ }^{226} \mathrm{Ra} / \mathrm{U}$ chronometrics has made it possible to demonstrate that marine carbonates from corals sampled in deep waters have developed in an open system with, in this particular case, an uptake of uranium leading to a significant reduction in U-Th ages (Pons-Branchu et al., 2005). But a reverse scenario may also take place, with the dispersal of the uranium leading to the overestimation of the age of the sample (Fruijtier et al., 2000). In other, more common cases, the use of two chronometrics (U-Th with ${ }^{226} \mathrm{Ra}$ or ${ }^{231} \mathrm{~Pa} / \mathrm{U}$ ) has on the contrary enabled the validation of the dates obtained for continental or marine calcareous deposits (Mortlock et al., 2005; Ghaleb et al., 2004; Chiu et al., 2006).

Even though they are difficult to implement for small samples of calcite removed from decorated walls, such cross-dating methods are essential in proposing a reliable chronology for these calcitic deposits whose geochemical development is always complex.

\section{ARCHAEOLOGICAL INTERPRETATIONS}

The preceding paragraphs describe the numerous difficulties inherent in the application of the U-Th method to dating cave art works, and the extreme caution that must be taken when interpreting the results in the case of a single analysis carried out on a calcite deposit covering such representations. There are two reasons for stating these reservations. First of all, there are the intrinsic factors linked to the hydrogeological phenomena involved and then there are the factors linked to the hypotheses imposed by the method.

In terms of the dating of stalagmitic formations, the application of the U-Th method to the dating of thin layers of calcite covering prehistoric art works presents a much more difficult problem, as we are unaware of which humid period the calcite formed in, or the duration of the phenomenon. If we analyze the entire thickness of the deposit, which is often the case, we obtain an average age that may be unrelated to the actual age of the prehistoric work. For the age determined to be similar to that of the age sought, the calcite must have been deposited immediately after the creation of the painting, deposition must have taken place over only a very brief period, and no further deposition must have occurred during the following millennia. Such 
a concatenation of circumstances must be exceptional. What is more likely is that calcite deposition will have occurred during periods in which the climatic conditions were favorable (humid), between the creation of the work and the present day, and that it will have taken place over a long period. If this is the case, the age that we will obtain will represent only a small fraction of the time that has actually elapsed.

\section{On the archaeological interest of a terminus ante quem}

Geochronologists are aware that this method provides only a terminus ante quem and that this can be far removed from the creative act that we wish to date. This is clearly the prevailing situation in the majority of cases involving dating calcite veils. The growth of the calcite veils is controlled principally by environmental factors (external temperature and precipitation) and, like the growth of speleothems, is favored by temperate, humid periods and slowed or halted in periods of cold, dry climatic conditions. Many of the calcite deposits covering cave art works may therefore be Tardiglacial or Holocene (the last 12,000 years) or may date from a period of relative warming during a glacial period, which moves us closer to the creation date of the works. The ages determined for the calcite veils may also represent an average of several phases of growth. However, this information provides useful elements for reflection once the validity of the ages has been verified on a methodological level. In this way, the oldest age obtained for a panel is an element that contributes to a geochronological discussion. This is the approach employed in the study of the cave of Creswell Crags in the United Kingdom (Pike et al., 2005), for which eleven UTh dates were obtained from calcareous concretions close to wall engravings attributed to the Paleolithic period. Six of the results fell between 850 and 5600 years, two around 8000 years, and among the three dates before 10,000 years, there were two in the interval $13,000-14,400$ years. The authors considered that these latter dates provided relevant information on the period in which the engravings were created, particularly as they fell into the calibrated interval $(13,000-15,600$ cal. BP $)$ deduced from the $14 \mathrm{C}$ dating of anthropomorphically modified bone splinters present in the archaeological level. Even if this coincidence does not provide irrefutable proof, it contributes to the accumulated geochronological data that enable human activity in the cave to be located in time.

The least informative results have been obtained from the strange red symbols from the cave of Santián (fig. 2). Abbé Breuil identified these as belonging to the earliest phase of Spanish Cantabrian Paleolithic art, and this is no doubt why Spanish prehistorians have attempted uranium series dating. Unfortunately the results of the two samples carried out have not provided any useful results, giving dates of $6552 \pm 50$ and $8090 \pm 390$ years respectively. While it is true that these dates do not contradict the attribution of the art works to the Upper Paleolithic, on the basis of the terminus ante quem principle, they do not provide any new information. In a great number of cases, the terminus ante quem obtained by U-Th is significantly later (i.e, more recent) than the age expected by archaeologists. For example, around two-thirds of the dates obtained by Pike et al. for the Cantabrian caves were post-Paleolithic, resulting from the recurrence of significant hydrological activity during the Holocene period. To resolve the question posed by the spread over time of the calcite formation, it is necessary to carry out a very fine analysis of the microstratigraphy of the deposits in order to separately date very thin layers. This was carried out successfully in the cave in East Timor mentioned above (Aubert et al., 2007) with the use of laser ablation in conjunction with the MCICPMS technique. Substantially different results have sometimes been reported for samples taken only a few centimeters apart. For example, in the cave of La Garma, a braid of calcite crossing the back of an ibex drawn on the wall (fig. 3) was attributed a thermoluminescence (TL) date of 34,175 years, while the same ridge was subject to three datings by U-Th: $26,100 \pm 960$; 26,800 \pm 480 and 28,800 \pm 1860 (González Sainz, 2003). In addition, a crust located a few decimeters lower down, superimposed over a second caprine drawing of a style identical to the former, has produced the much older U-Th date of $37,000 \pm 1100$ years, enlarging still further the span of uncertainty regarding the real age of this panel with red figures. The mismatch between these values obtained by two different techniques within a radius of barely $50 \mathrm{~cm}$ demonstrates that either the calcareous deposits were subject to phenomena relating to open geochemical systems as described above, or that the calcite deposits post-dating the representations are not contemporary.

In this way, the uncertainties linked to the duration of the formation of the deposit and to local variations mean that we obtain only average values which act as a terminus ante quem that may in fact be relatively far removed from reality. The question deserves discussion in relation to the oldest ages appearing in the article by Pike et al. (2012), particularly for the three dates in excess of 35,000 years in which the authors show particular interest, as they throw into question currently accepted chronological models. Given their archaeological impact, it is essential to confirm the validity of these results by means of more detailed geochemical analysis and by other independent datings.

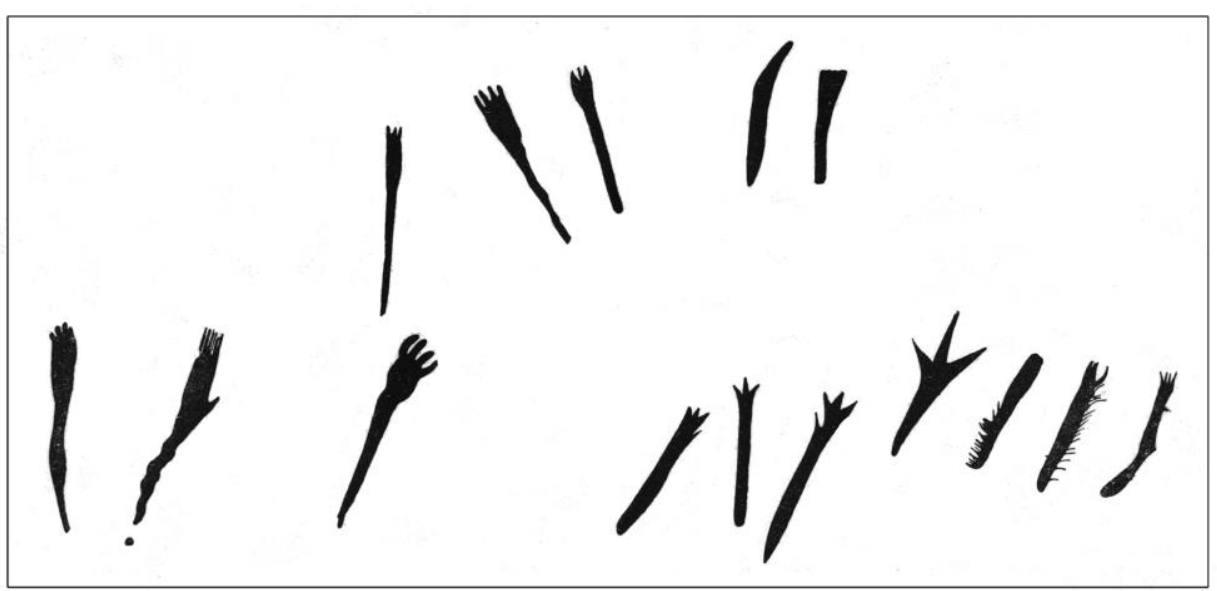

Fig. 2 - Santián cave (Cantabria). H. Breuil attributed this set of red symbols to the earliest phase of Cantabrian rock art Aurignacian (tracing by H. Breuil).

Fig. 2 - Grotte de Santián (Cantabrie). H. Breuil attribuait cet ensemble de signes rouges à la phase la plus ancienne de l'art pariétal cantabrique - Aurignacien (relevé H. Breuil). 
The chronological models for cave art, in particular those applying to the Cantabrian region, have been subject to major fluctuations over time. The first model was that suggested by Abbé Breuil, who attributed a large number of Cantabrian works to the Aurignacian, particularly in the caves of Altamira, El Castillo, Hornos de la Peña, La Clotilde and La Peña de Candamo. Leroi-Gourhan, in his revision of the Breuil system, is in turn in favor of a much shorter chronology from which the Aurignacian is practically absent. Regarding the Cantabrian region, he attributes the majority of the pre-Magdalenian works to his style III, i.e. to the Solutrean and lower Cantabrian Magdalenian (such as the 'black series' at Altamira, El Castillo, La Pasiega A, Las Chimeneas and Covalanas), with only rare works being attributed to the Gravettian and style II. Over recent decades, Spanish researchers have carried out an in-depth re-examination of the Cantabrian stylistic chronology, which has led them to propose older dates for a number of works in relation to Leroi-Gourhan's proposals. This is in particular the case for the red punctuated figures whose origin is today attributed more readily to the Gravettian or even the Aurignacian on the basis of direct dates of calcareous crusts by thermoluminescence (TL) and by uranium series (González Sainz, 2003 and 2007; Garate, 2010). In the cave of Pondra, for example, a calcareous crust was dated to 27,000 years by TL, thereby providing an ante quem age for an underlying red deer protome (fig. 4). We have mentioned above the case of the red figures from La Garma dated by TL and UTh to between 26,000 and 37,000 years. Finally, we should examine the ${ }^{14} \mathrm{C}$ datings carried out on small pieces of charcoal collected from drawings and paintings in the decorated caves of Altamira, El Castillo, Covaciella and La Garma, all of which corresponded to the Magdalenian period (Valladas et al., 2001a and 2013); these dates were also close to those obtained by the same method for the faunal remains discovered in the archaeological levels of these caves (with the exception of that for Covaciella, for which no archaeological material has been dated), thereby confirming the presence of prehistoric humans during this period.

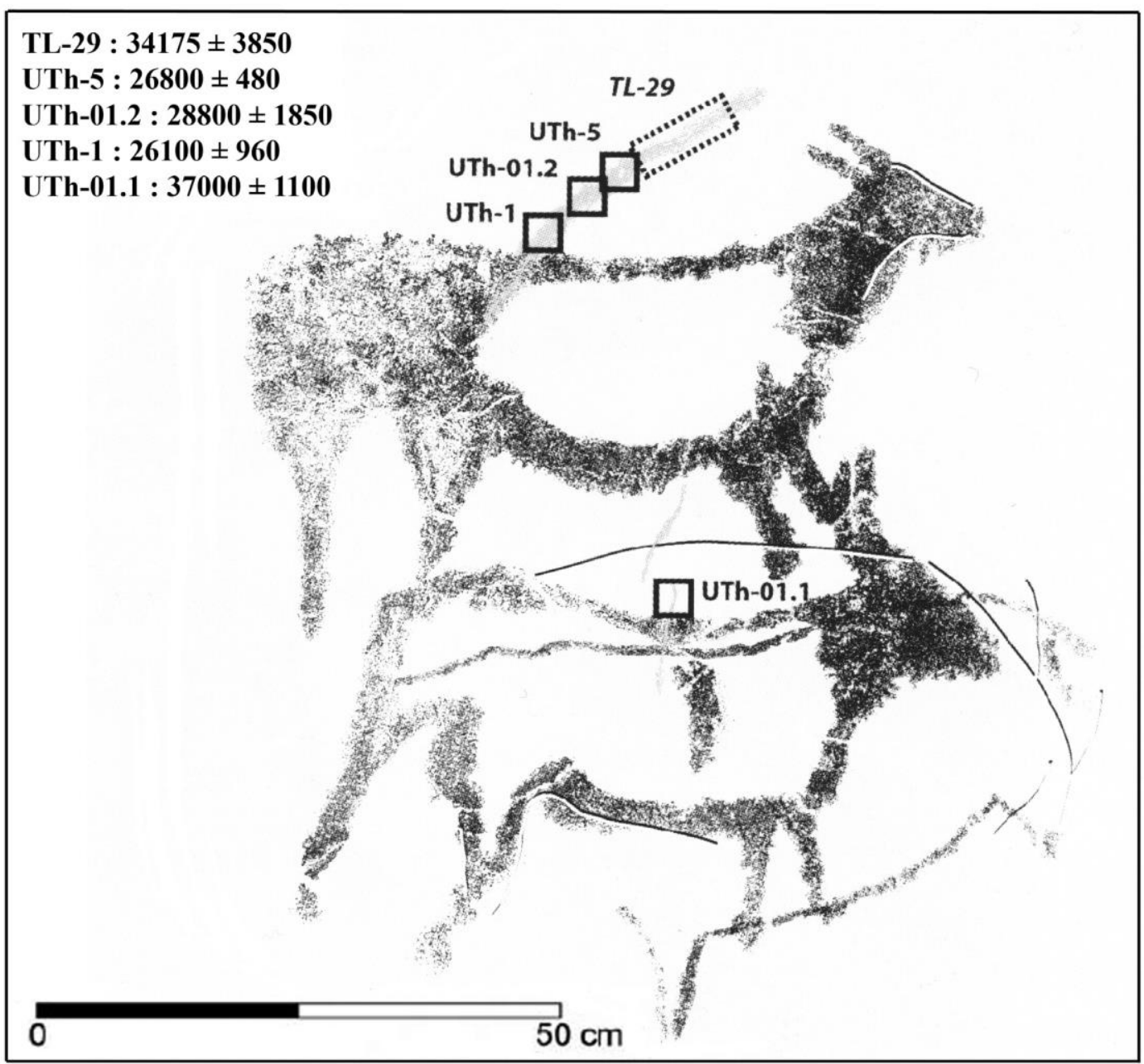

Fig. 3 - Lower cave at La Garma (Cantabria). Location of samples taken for TL and U-Th dating (after González Sainz, 2003).

Fig. 3 - Grotte inférieure de La Garma (Cantabrie). Emplacement des prélèvements pour datations par TL et U/Th (d'après González Sainz, 2003).218 Bulletin de la Société préhistorique française

\section{Modern Humans or Neanderthals?}

Particular interest has been paid by Pike et al. (2012) to the oldest date in the series $(41,400 \pm 570 \mathrm{BP}$ obtained for the dating of a calcite veil covering a red disc in the Panel de las manos in the cave of El Castillo). These authors take advantage of the fact that this date is located within the confines of the transition between Neanderthals and the first Modern Humans to introduce the hypothesis that Neanderthals may have been the authors of these red marks. While there is no archaeological argument in favor of such an assertion, an ambiguous phrase such as "it cannot be ruled out that the earliest paintings were symbolic 
expressions of the Neanderthals" suffices to introduce doubt, even if the double negative appears to mitigate the comment. Journalists have perfectly understood the implied message and have made full use of the journalistic opportunity, as noted with clairvoyance by J. Clottes: "Despite the apparent caution in the wording, the media understood the gift perfectly and titled on the Neandertal issue. In theory, this is of course possible, but to re-launch such a hypothesis on such flimsy fragile evidence is not scientifically serious." (Clottes, 2012, p. 6) It is indeed rather foolhardy to put forth such a provocative interpretation on the basis of a single date. We must remain cautious and refrain from any excessive exploitation of these results until independent chronological and chronometric data are available to confirm them.

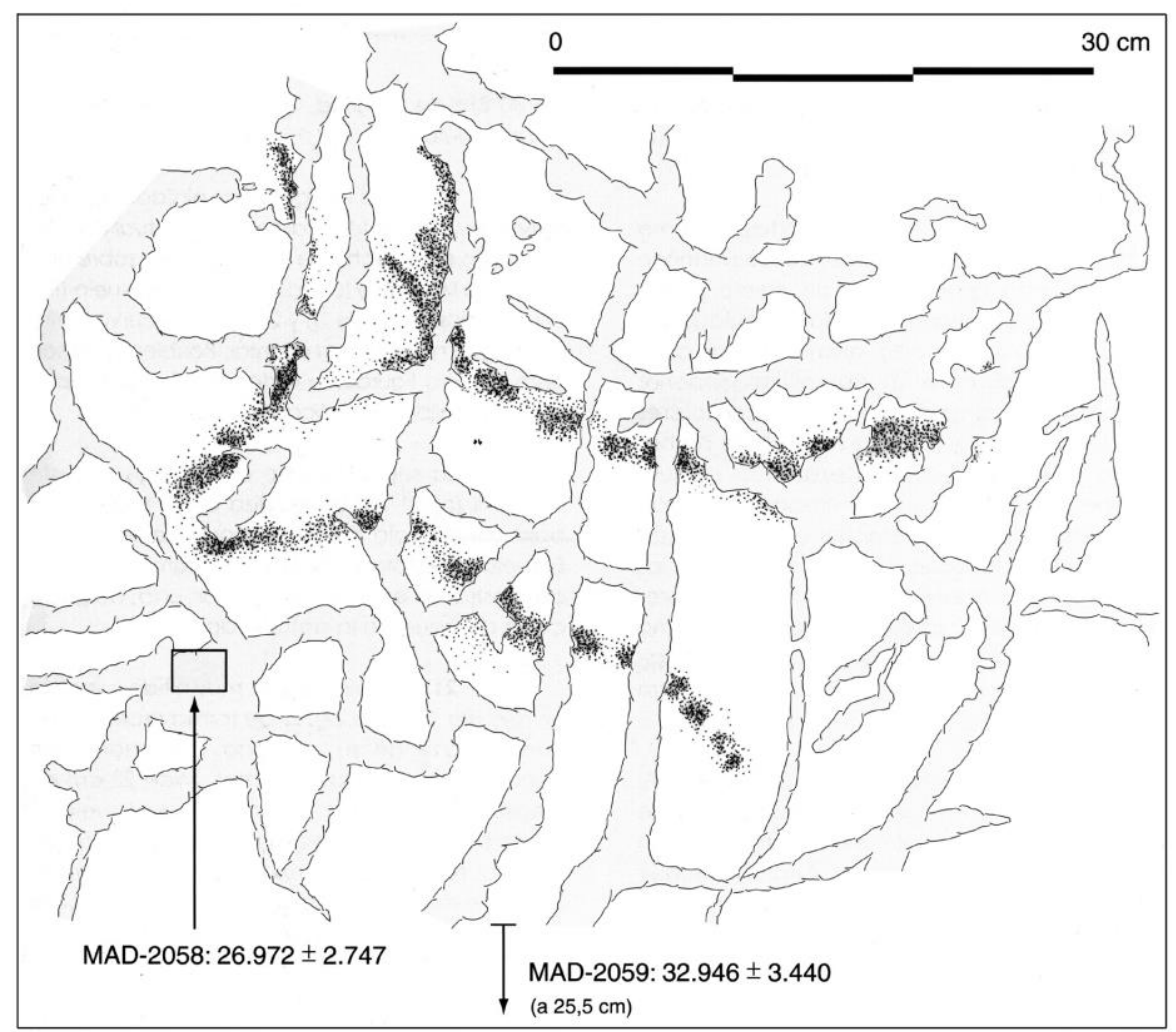

Fig. 4 - Pondra cave (Cantabria). The age of the red deer protome has been estimated by TL dating of the calcite underlying and superimposed over the figure, providing a terminus post quem and a terminus ante quem (after González Sainz and San Miguel Llamosas, 2001).

Fig. 4 - Grotte de Pondra (Cantabrie). L'âge de ce protomé de cerf rouge a été estimé grâce à la datation par TL de la calcite sous-jacente et de la calcite superposée à la figure, donnant un terminus post quem et un terminus ante quem (d'après González Sainz et San Miguel Llamosas, 2001).

An extremely interesting graphic presented in the article in Science (Pike et al., 2012, fig. 2) clearly shows that the date of 41,000 years fits perfectly within the chronological limits that the authors attribute to the Aurignacian and proto-Aurignacian occupations of the Cantabrian region. This is confirmed by numerous calibrated radiocarbon dates (Reimer et al., 2013). The most recent datings of archaeological material by ${ }^{14} \mathrm{C}$, particularly those using the technique of ultra-filtration to purify the bone collagen, confirm that, throughout Europe, from the Cantabrian region and the Pyrenees to Germany (Geissenklösterle) and Italy (Fumane), the archaeological levels attributed to the Proto-Aurignacian and Classic Aurignacian are more than 40,000 years old according to the calibration of the $14 \mathrm{C}$ dates (table 1).

Without supporting the assertion that this Aurignacian industry was produced by the Neanderthals, which no prehistorian today claims, we must admit that Anatomically Modern Humans were already present in western Europe well before 40,000 years ago. The radiocarbon dates that we currently have available situate the earliest symbolic wall representations at between 38,000 and 34,000 cal. BP (fig. 5) and the first figurative portable works of the Swabian Jura (Geissenklösterle, Hohle Fels, Vogelherd and Hohlenstein-Stadel) between 39,000 and 36,500 cal. BP (average of available AMS dates). Given the rapidity of dissemination of artistic practices throughout Europe and the scale of current margins of error, we would not be at all surprised if even earlier dates were soon announced for works of Aurignacian cave art. If new studies confirm an age greater than 40,000 years for the oldest paintings in the El Castillo cave, there will be no need to invoke Neanderthals.

The hypothesis according to which the Neanderthals could have been the authors of the earliest cave art representations is not new. It forms part of a recurring — sometimes polemical — discussion on the origin of symbolic thought which opposes those in favor of independent development of the Neanderthals and the supporters of the view that there was acculturation following contact with the Aurignacians. The debate relates in particular to the elements of personal ornamentation revealed in the Chatelperronian levels, accepted in turn as evidence for independent Neanderthal production or as the result of acculturation (cf. discussion in D'Errico et al., 1998).

It is interesting to observe that, while the majority of prehistorians no longer defend the model of a unilinear development as proposed by Leroi-Gourhan, many of them still accept conceptual outlines according to which what is older must be less welldeveloped and the figurative must be later than the non-figurative (González Sainz, 1999; Alcolea and Balbín, 2007). 


\begin{tabular}{|c|c|c|c|c|c|}
\hline Site & Archaeological layer & Lab. ref. & Date 14C BP & $\begin{array}{l}\text { Date cal. BP 95\% } \\
\text { (IntCal13) }\end{array}$ & Reference \\
\hline Caminade & c. $\mathrm{G}$ & GifA-97185 & $37,200 \pm 1500$ & $44,750-38,930$ & Bordes 2000 \\
\hline Isturitz & c. $\mathrm{C} 4 \mathrm{c} 4$ & $\begin{array}{l}\text { AA-69181 } \\
\text { AA-69183 } \\
\text { AA-69185 }\end{array}$ & $\begin{array}{l}36,800 \pm 860 \\
37,580 \pm 780 \\
36,990 \pm 720\end{array}$ & $\begin{array}{l}42,720-39,770 \\
43,170-40,660 \\
42,620-40,210\end{array}$ & $\begin{array}{l}\text { Szmidt et al., } 2010 \\
\text { Szmidt et al., } 2010 \\
\text { Szmidt et al., } 2010\end{array}$ \\
\hline Cueva Morín & c. 8 & GifA-96263 & $36,590 \pm 770$ & $42,440-39,730$ & $\begin{array}{l}\text { Maillo Fernández et } \\
\text { al., } 2001\end{array}$ \\
\hline La Viña & c. XIII & Ly-6390 & $36,500 \pm 750$ & $42,350-39,670$ & Fortea, 1995 \\
\hline El Castillo & c. $18 \mathrm{~b} 2$ & OxA-2474 & $38,500 \pm 1300$ & $45,350-40,710$ & Hedges et al., 1994 \\
\hline El Castillo & c. 16 & GifA-95539 & $34,300 \pm 1000$ & $41,140-36,440$ & $\begin{array}{l}\text { Cabrera-Valdes et } \\
\text { al., } 2002\end{array}$ \\
\hline Geissenklösterle & c. IIIa & $\begin{array}{l}\text { OxA-21745 } \\
\text { OxA-21746 }\end{array}$ & $\begin{array}{l}36,650 \pm 750 \\
36,850 \pm 800\end{array}$ & $\begin{array}{l}42,440-39,820 \\
42,650-39,930\end{array}$ & $\begin{array}{l}\text { Higham et al., } 2012 \\
\text { Higham et al., } 2012\end{array}$ \\
\hline Geissenklösterle & c. IIIb & $\begin{array}{l}\text { OxA-21743 } \\
\text { OxA-21723 } \\
\text { OxA-21721 }\end{array}$ & $\begin{array}{l}36,100 \pm 700 \\
37,800 \pm 900 \\
37,300 \pm 800\end{array}$ & $\begin{array}{l}40,010-39,330 \\
43,670-40,630 \\
42,970-40,350\end{array}$ & $\begin{array}{l}\text { Higham et al., } 2012 \\
\text { Higham et al., } 2012 \\
\text { Higham et al., } 2012\end{array}$ \\
\hline Fumane & A2 & $\begin{array}{l}\text { OxA-17981 } \\
\text { OxA-17569 } \\
\text { OxA-17570 }\end{array}$ & $\begin{array}{l}33,890 \pm 220 \\
35,640 \pm 220 \\
35,180 \pm 220\end{array}$ & $\begin{array}{l}38,900-37,720 \\
40,860-39,700 \\
40,320-39,140\end{array}$ & $\begin{array}{l}\text { Broglio et al., } 2009 \\
\text { Broglio et al., } 2009 \\
\text { Broglio et al., } 2009\end{array}$ \\
\hline
\end{tabular}

Table 1 - ${ }_{14} \mathrm{C}$ dates from some western European with archaeological levels attributed to the Proto-Aurignacian or early Aurignacian. Dates calibrated to 2 sigma (probability 95\%) with Intcal 13 (OxCal 4.2, Reimer et al., 2013).

Tabl. 1 - Dates ${ }_{14} C$ de quelques sites d'Europe occidentale ayant livré des niveaux archéologiques attribués au

Protoaurignacien ou à l'Aurignacien ancien. Dates calibrées à 2 sigma (probabilité $95 \%$ ) avec Intcal 13 (OxCal 4.2,

Reimer et al., 2013).

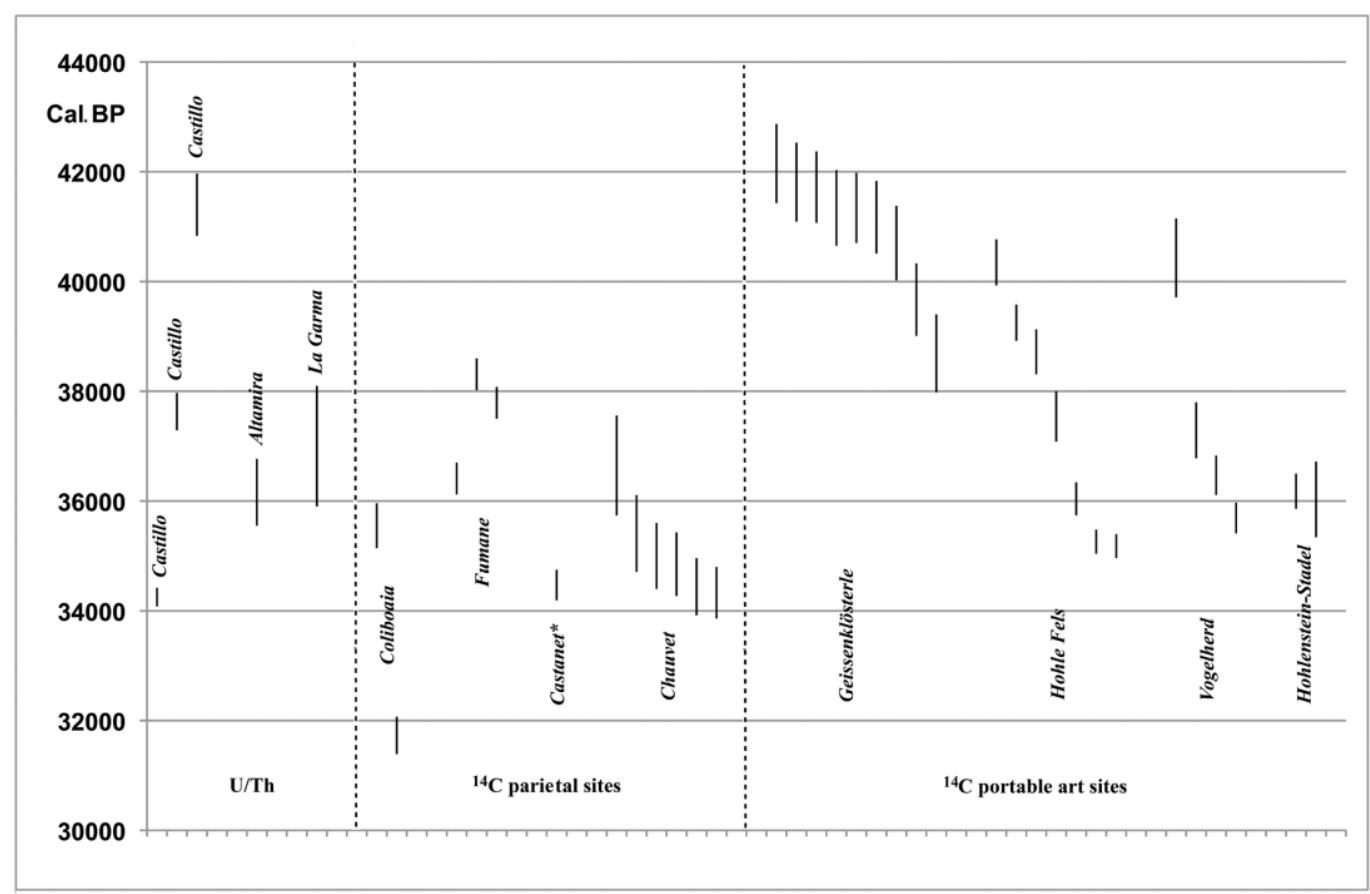

Fig. 5 - Calibrated U-Th and ${ }_{14} \mathrm{C}$ dates in excess of 30,000 years for European rock art sites and deposits of portable art (Castanet*: Bayesian probability on the basis of seven dates from the North sector, cf. White et al., 2012). ${ }_{14} \mathrm{C}$ dates calibrated with Intcal 13 (OxCal 4.2, Reimer et al., 2013), probability 68\% ( $\pm 1 \sigma)$.

Fig. 5 - Dates U/Th et ${ }_{14}$ C calibrées supérieures à 30000 ans dans des sites pariétaux et des gisements d'art mobilier européens. (Castanet* : probabilité bayesienne portant sur 7 dates du secteur nord, $c f$. White et al., 2012). Dates ${ }_{14} C$ calibrées avec Intcal 13 (OxCal 4.2, Reimer et al., 2013), probabilité $68 \%$ ( $\pm 1 \sigma)$.

This assumption is based in particular on the existence of deeply engraved linear traces attributed to the Aurignacian in the shelters of La Viña and El Conde (Asturias) and on the rarely questioned conviction that the primordial component of early cave art in the Cantabrian caverns (El Castillo, Llonin, Tito Bustillo, Peña de Candamo and La Garma) is essentially constituted of rods, meandering shapes, double sticks, blown discs, alignments and clouds of punctuations, together with representations of female sexual organs and negative hands.

The authors of the Science article agree more or less consciously with this paradigm. They suggest that the Neanderthals could have been the source of cave art, but the graphical range attributed to them is particularly 'primitive' and limited to dots, negative hands or lines. This approach equates to making the Neanderthal an early version of Homo sapiens, who in turn would be able to design and execute well-developed figures. Would it not be easier to admit that Neanderthal groups did not feel the imperative need to produce complex graphical symbols in this specific material form because their collective functioning in this area was different than that of Homo sapiens? This recurring quest for a 'rudimentary' Neanderthal art (roughly corresponding to the 'pre-figurative' stage in Leroi-Gourhan's 1965 classification) that would constitute the origins of the art of Homo sapiens appears to us the reflection of our incapacity as researchers to conceive of another approach to the subject. 


\section{CONCLUSION}

For more than a century, the search for dating methods enabling a precise reconstruction of the chronology of Palaeolithic art in all its complexity has been a major objective. Direct dating of organic pigments by ${ }_{14} \mathrm{C}$ accelerator mass spectrometry represents a genuine advance, but the method has limited application as drawings carried out with charcoal are not very common. The prospects offered by the dating of calcareous deposits covering prehistoric art works by techniques such as uranium series dating are immense, as they are applicable to the contexts of all sorts of painted and engraved works.

Although the technique has been well-proven in the case of large speleothems, it is still experimental in its application to fine calcite layers. When such deposits are analyzed as a whole, average ages are obtained that may be far removed from the time of the decoration. It is necessary to wait for the micro-stratigraphical analysis of thin layers taken from the thickness of the deposits to be common practice before we will be capable of reconstructing the complete history of these deposits over time and accurately locating the date of the artistic creation on the cave wall (Aubert et al., 2007).

The methodology employed in the Spanish caves by Pike et al. (2012) does not incite great confidence in some of the dates they obtained, given the possible existence of uncontrolled bias; the great variability of ${ }_{234} \mathrm{U} /{ }_{238} \mathrm{U}$ ratios (up to a factor of four in some caves) is not discussed. In addition, the uranium levels are not provided in the article, making impossible any discussion of the geochemical development of the systems in question. Finally, the lack of comparison with other dating methods is also regrettable. This is particularly the case with the oldest dates obtained by the U-Th method in the Altamira and El Castillo caves. Even if, hypothetically, we accept them without reservation, three of these fall between 34,250 and 37,630 calendar years before present, which corresponds to those that we already have for cave art in Castanet and Chauvet in France, Fumane in Italy, Coliboaia in Romania and for the portable art of the Swabian Jura (fig. 5 and table 1). These dates would therefore not be exceptional even if they were to be confirmed in the future. Even the oldest of these, the date of 41,400 $\pm 570 \mathrm{BP}$ obtained for a red dot in El Castillo, falls perfectly within the currently known limits of the Aurignacian advance and in no way justifies the media frenzy that followed the appearance of the article in Science. It is unfortunate that the least scientifically plausible hypothesis (ultimately based on a single isolated date) is that which attracted the attention of the media as a result of its sensational nature. The discussions resulting from U-Th datings recently obtained from calcite veils make clear the necessity of always approaching the geochronological study of cave art in the context of current multi-disciplinary studies of decorated caves, and their archaeological context. It is only by means of this sharing of scientific data, and as a result of joint discussion that these datings will be fully justified and appreciated.

Acknowledgements: The authors would like to thank the three anonymous reviewers and the editor, whose comments have helped improve the text.

\section{BIBLIOGRAPHICAL REFERENCES}

Alcolea González J. J., Balbín Behrmann R. de (2007) - ${ }_{14}$ C et style. La chronologie de l'art pariétal à l'heure actuelle, L'Anthropologie, 111, pp. 435 - 466.

Arnold M., Bard E., Maurice P., Duplessy J.-C. (1987) - ${ }_{14}$ C dating with the Gif-sur-Yvette Tandetron accelerator: status report, Nuclear Instruments and Methods in Physics Research, B 29, pp. $20-123$.

Aubert M., O'connor S., Mcculloch M., Mortimer G., Watchman A., Richier-Lafleche M. (2007) - Uranium-series dating rock art in East Timor, Journal of Archaeological Science, 34, pp. 991 - 996.

Bard E., Hamelin B., Fairbanks R. G., Zindler A. (1990) - Calibration of the ${ }_{14}$ C timescale over the past 30,000 years using mass spectrometric U-Th ages from Barbados corals, Nature, 345, pp. $405-410$.

Bednarik R. G. (2012) - U-Th analysis and rock art: a response to Pike et al., Rock Art Research, 29, 2, pp. 244 - 246.

Bischoff J., García-Diez M., González Morales M. R., Sharp W. (2003) - Aplicación del método de series de Uranio al grafismo rupestre de estilo paleolítico: el caso de la cavidad de Covalanas (Ramales de la Victoria, Cantabria). Veleia,20, pp143-150.

Bordes J.-G. (2000) - La séquence aurignacienne de Caminade revisitée : l'apport des raccords d'intérêt stratigraphique, Paléo, 12 , pp. $387-407$.

Borsato A., Quinif Y., Bini A., Dublyansky Y. (2003) - Open-system alpine speleothems: implications for U-series dating and paleoclimate reconstructions, Studi Trentini di Scienze Naturali, Acta Geologica, 80, pp. 71 - 83.

Broglio A., De Stefani M., Gurioli F., Pallecchi P., Giachi G., Higham T., Brock F. (2009) - L'art aurignacien dans la décoration de la grotte de Fumane, L'Anthropologie, 113, pp. 753 - 761.

Cabrera-Valdés V., Bernaldo de Quirós F., Maíllo- Fernández J. M., Valladas H., Lloret M. (2002) - El Auriñaciense arcaico de El Castillo (Cantabria) : descripción tecnológica y objetivos de la producción, in F. Bon, J. M. Maíllo-Fernández and D. Ortega (eds.), Autour des concepts de Protoaurignacien, d'Aurignacien archaïque, initial et ancien, Madrid, Universidad Nacional de Educacion a Distancia, Facultad de Geografia e Historia (Espacio, Tiempo y Forma, 15), pp. 67 - 86.

Cheng H., Edwards R. L., Murrell M. T., Benjamin T. M. (1998) - Uranium-thorium-protactinium dating systematics, Geochimica et Cosmochimica Acta, 6, 21-22, pp. 3437 - 3452.

Chiu T. C., Fairbanks R. G., Cao L., Fairbanks T. W., Bloom A. L. (2006) - Redundant ${ }_{230} \mathrm{Th} /{ }_{234} \mathrm{U} / 238 \mathrm{U},{ }_{231} \mathrm{~Pa} / 235 \mathrm{U}$ and ${ }_{14} \mathrm{C}$ dating of fossil corals for accurate radiocarbon age calibration, Quaternary Science Reviews, 25, 17-18, pp. 2431- 2440.

Clottes J. (2012) - Datations U-Th, évolution de l'art et Néandertal, International Newsletter on Rock Art, 64, pp. 1- 6.

D’Errico F., Zilhao J., Jullien M., Baffier D., Pelegrin J. (1998) - Neanderthal acculturation in western Europe? A critical review of the evidence and its interpretation, Current Anthropology, 39, suppl., S1-44.

Edwards R. L., Chen J. H., Wasserburg G. J. (1987) - ${ }_{238} \mathrm{U}-234 \mathrm{U}-230 \mathrm{Th}-232 \mathrm{Th}$ systematics and the precise measurement of time over the past 500,000 years, Earth Planet, Science Letters, 81, pp. 175 -192.222 Bulletin de la Société préhistorique française 
Fleischer R. L., Raabe O. G., (1978) - Recoiling alpha-emitting nuclei; mechanisms for uranium-series disequilibrium, Geochimica et Cosmochimica Acta, 42, 7, pp. $973-978$.

Fontugne M., Shao Q., Frank N., Thil F., Guidon N., Boeda E. (2013) - Cross dating (Th/U-14C) of calcite covering prehistoric paintings at Serra da Capivara National Park, Piaui, Brazil, Radiocarbon, 55, 2-3, pp. $1191-1198$.

Fruijtier C., Elliott T., Schlager W. (2000) - Mass-spectrometric ${ }_{234} \mathrm{U}-230$ Th ages from the Key Largo Formation, Florida Keys, United States: Constraints on diagenetic age disturbance, Geological Society of American Bulletin, 112, 2, pp. 267 - 277.

Fortea Perez J. (1995) - Abrigo de la Viña. Informe y primera valoración de las campañas 1991 a 1994, Excavaciones arqueológicas en Asturias 1991-94 (Oviedo), 3, pp. 19 - 32.

Gárate Maidagán D. (2010) - Las ciervas punteadas en las cuevas del Paleolítico. Una expresión pictórica propia de la cornisa cantábrica, Donostia, Sociedad de Ciencias (suplemento Munibe, 33), 306 pp.

Genty D., Massault M., Gilmour M., Baker A., Verheyden S., Keppens E. (1999) - Calculation of past dead carbon proportion and variability by the comparison of AMS ${ }_{14} \mathrm{C}$ and TIMS U/Th ages on two Holocene stalagmites, Radiocarbon, 41, 3, pp. $251-270$.

Genty D., Baker A., Massault M., Proctor C., Pons- Branchu E., Hamelin B. (2001) - Dead carbon in stalagmites: carbonates bedrocks vs ageing of soil organic matter. Implications for ${ }_{13} \mathrm{C}$ variations in speleothems, Geochimica et Cosmochimica Acta, 65, 20, pp. $3443-3457$.

Ghaleb B., Pons-Branchu E., Deschamps P. (2004) - Improved method for radium extraction from environmental samples for determination by thermal ionization Mass spectrometry, Journal of Analytical Atomic Spectrometry, 19, 7, pp. 906 - 910.

González Sainz C. (1999) - Algunos problemas actuales en la ordenación cronológica del arte paleolítico en Cantabria, in I Encuentro de Historia de Cantabria, proceedings of the conference (Santander, 16-19 December 1996), Santander, Universidad de Cantabria, pp. 149 - 166.

González Sainz C. (2003) - El conjunto parietal paleolítico de la Galería inferior de La Garma (Cantabria). Avance de su organización interna, in R. de Balbín Behrmann and P. Bueno Ramírez (eds.), El arte prehistórico desde los inicios del siglo XXI, proceedings of the international symposium (Ribadesella, Spain, 2002), Oviedo, Asociación Cultural Amigos de Ribadesella, pp. $201-222$.

González Sainz C. (2007) - Los grupos humanos del paleolítico superior y el primer arte figurativo, in M. Suárez Cortina (dir.), Historia de Cantabria, Santander, El Diario Montañes (supll. del 15-II-2007), pp. 25 - 32.

González Sainz C., San Miguel Llamosas C. (2001) - Las cuevas del desfiladero. Arte rupestre paleolítico en el valle del río Carranza (Cantabria-Vizcaya), Santander, Universidad de Cantabria, 225 pp.

Goslar T., Herchman H., Pazdur A. (2000) - Comparison of U-series and radiocarbon dates of speleothems, Radiocarbon, 42, 3 , pp. $403-414$

Hedges R. E. M., Housley R. A., Bronk Ramsey C., Van Kliken G. J. (1994) - Radiocarbon dates from the Oxford AMS system: Archaeometry Datelist 18, Archaeometry, 36, 2, pp. $337-374$.

Hellstrom J. (2006) - U-Th dating of speleothems with high initial ${ }_{230}$ Th using stratigraphical constraint, Quaternary Geochronology, 1, 4, pp. $289-295$.

Hellstrom J., Mcculloch M. (2000) - Multi-proxy constraints on the climatic significance of trace elements records from a New Zealand speleothem, Earth and Planetary Science Letters, 179, pp. 287 - 297.

Higham T., Basell L., Jacobi R., Wood E., Bronk Ramsey C., Conard N. J. (2012) - Testing models for the beginnings of the Aurignacian and the advent of figurative art and music: The radiocarbon chronology of Geißenklösterle, Journal of Human Evolution, 62, pp. $664-676$.

Hoffmann D. L., Warren Beck J., Richards D. A., Smart P. L., Singarayer J. S., Ketchmark T., Hawkesworth C. J. (2010) Towards radiocarbon calibration beyond 28 ka using speleothems from the Bahamas, Earth and Planetary Science Letters, 289 , pp. $1-10$

Hua Q., Mcdonald J., Redwood D., Drysdale R., Lee S., Fallon S., Hellstrom J. (2012) - Robust chronological reconstruction for young speleothems using radiocarbon, Quaternary Geochronology, 14, pp. $67-80$.

Jaillet S. (2000) - Un karst couvert de bas-plateau : le Barrois. Structure, fonctionnement, évolution, PhD thesis. Bordeaux 3 University.

Labonne M., Hillaire-Marcel C., Ghaleb B., Goy J. L. (2002) - Multi-isotopic age assessment of dirty speleothem calcite: an example from Altamira Cave, Spain, Quaternary Science Reviews, 21, pp. $1099-1110$.

Leroi-Gourhan A. (1965) - Préhistoire de l'art occidental, Paris, Mazenod, 482 pp.

Li W. X., Lundberg J., Dickin A. P., Ford D. C., Schawarcz H. P., Mcnutt R., Williams D. (1989) - High-precision massspectrometric uranium-series dating of cave deposits and implications for palaeoclimate studies, Nature, 339, pp.534-536.

Maíllo Fernández J. M., Valladas H., Cabrera Valdés V., Bernaldo de Quirós F. (2001) - Nuevas dataciones para el Paleolítico superior de Cueva Morín (Villanueva de Villaescusa, Cantabria). Serie I, Prehistoria y Arqueologia Espacio, Tiempo y Forma, 14, pp. $145-150$.

Mortlock R. A., Fairbanks R. G., Chiu T.-C., Rubenstone J. (2005) - ${ }_{230} \mathrm{Th} / 234 \mathrm{U} / 238 \mathrm{U}$ and ${ }_{231} \mathrm{~Pa} / 235 \mathrm{U}$ ages from a single fossil coral fragment by multi-collector magnetic-sector inductively coupled plasma mass spectrometry, Geochimica et Cosmochimica Acta, 69, 3, pp. $649-657$.

Osmond J. K., Ivanovich M. (1992) - Uranium-series mobilization and surface hydrology, in M. Ivanovich and R. S. Harmon (eds.), Uranium-series disequilibrium; applications to earth, marine, and environmental sciences, Oxford, Clarendon Press, pp. $259-289$.

Pike A. W. G., Gilmour M., Pettitt P., Jacobi R., Ripoll S., Bahn P., Muñoz F. (2005) - Verification of the age of the Palaeolithic rock art at Creswell, Journal of Archaeological Science, 32, pp. 1649 -1655.Tome 111, numéro 2, avril-juin 2014, p. 211224. 223 
Pike A. W. G., Hoffmann D. L., García-Diez M., Pettitt P. B., Alcolea J., De Balbín R., González Sainz C., De Las Heras C., Lasheras J. A., Montes R., Zilhao J. (2012) - U-Series Dating of Paleolithic Art in 11 Caves in Spain, Science, 336 (15 June 2012), pp. 1409 - 1413 (supplementary materials: www.sciencemag.org/cgi/content/ full/336/6087/1409/DC1).

Plagnes V., Causse C., Fontugne M., Valladas H., Chazine J.-M., Fage L.-H. (2003) - Cross dating (Th/U- $\left.{ }_{14} \mathrm{C}\right)$ of calcite covering prehistoric paintings in Borneo, Quaternary Research, 60, 2, pp. $172-179$.

Pons-Branchu E. (2001) - Datation haute résolution de spéléothèmes $\left(230 T h / 234 \mathrm{U}\right.$ et $\left.{ }_{226} \mathrm{Ra} / 238 \mathrm{U}\right)$. Application aux reconstitutions environnementales autour des sites du Gard et de Meuse / Haute-Marne, PhD thesis. Aix-Marseille II University.

Pons-Branchu E., Hillaire-Marcel C., Ghaleb B., Deschamps P., Sinclair

D. (2005) - Early diagenesis impact on precise U-series dating of Deep-Sea corals. Example of a 100-200 years old Lophelia Pertusa sample from NE Atlantic, Geochimica et Cosmochimica Acta, 69, 20, pp. 4865 - 4879.

Reimer P. J., Bard E., Bayliss A., Beck J. W., Blackwell P. G., Bronk Ramsey C., Buck C. E., Cheng H., Edwards R. L., Friedrich M., Grootes P. M., Guilderson T. P., Haflidason H., Hajdas I., Hatté C., Heaton T. J., Hoffman D. L., Hogg A. G., Hughen K. A., Kaiser K. F., Kromer B., Manning S. W., Reimer R. W., Richards D. A., Scott E. M., Southon J. R., Staff R. A., Turney C. S. M., Van Der Plicht J. (2013) - IntCal13 and Marine13 Radiocarbon Age Calibration Curves 0 50,000 Years cal. BP, Radiocarbon, 55 (4), pp. $1869-1887$.

Szmidt C., Normand C., Burr G. S., Hodgins G. W. L., Lamotta S. (2010) - AMS ${ }_{14}$ C dating the Protoaurignacian/Early Aurignacian of Isturitz, France. Implications for Neanderthal - modern human interaction and the timing of technical and cultural innovations in Europe, Journal of Archaeological Science, 37, pp. 758 - 768.

Thurber D. L., Broecker W. S., Blanchar R. L., Potratz H. A. (1965) - Uranium-series ages of Pacific atoll coral, Science, 149, pp. $55-68$

Valladas H., Tisnerat-Laborde N., Cachier H., Arnold M., Bernaldo De Quirós F., Cabrera-Valdés V., Clottes J., Courtin J., Fortea Pérez J., González Sainz C., Moure-Romanillo A. (2001a) - Radiocarbon AMS dates for Paleolithic cave paintings, Radiocarbon, 43, 2B, pp. 977 - 986.

Valladas H., Clottes J., Geneste J. M., Garcia M., Arnold M., Cachier H., Tisnerat-Laborde N. (2001b) - Evolution of Prehistoric Cave Art, Nature, 413, 479.

Valladas H., Genty D., Kaltnecker E., Quiles A., Tisnerat-Laborde N., Arnold M., Moreau C., Baffier D., Cleyet-Merle J.-J., Clottes J., Girard M., Monney J., Montes R., González Sainz C., Sanchidrián J. L., Simonnet R. (2013) - Dating French and Spanish prehistoric decorated caves in their archaeological contexts, Radiocarbon, 55 (2-3), pp. 1422 - 1431.

Van N. H., Lalou C. (1969) - Comportement géochimique des isotopes des familles de l'uranium et du thorium dans les concrétionnements des grottes : application à la datation des stalagmites, Comptes rendus hebdomadaires des séances de l'Académie des sciences, série D, 269, pp. 560 - 563.

Vogel J. C., Krinfeld J. (1997) - Calibration of radiocarbon dates for the Late Pleistocene using U/Th dates on stalagmites, Radiocarbon, 39, pp. $27-32$.

White R., Mensan R., Bourrillon R., Cretin C., Higham T. F. G., Clarke A. E., Sisk M. L., Tartar E., Gardère P., Goldberg P., Pelegrin J., Valladas H., Tisnerat-Laborde N., De Sanoit J., Chambellan D., Chiotti L. (2012) - Context and dating of Aurignacian vulvar representations from Abri Castanet, France, Proceedings of the National Academy of Sciences, May 29, 109,22, pp. $8450-8455$.

Zhao J. X., Yu K. F., Feng Y. X. (2009) - High-precision ${ }_{238} \mathrm{U}-{ }_{234} \mathrm{U}-{ }_{230}$ Th disequilibrium dating of the recent past: a review, Quaternary Geochronology, 4, 5, pp. 423 - 433. 224 Bulletin de la Société préhistorique française 